\title{
J. Habermas'ın Rasyonalite Projesinde Zenginleşmenin Doğru Yönetimi
}

\author{
Ahmet Yavuz ÇAMLI ${ }^{1}$
}

$\ddot{\mathrm{O} z}$

Modern hayatta bireysel ve kurumsal faaliyetler çıkar yönelimli amaç-rasyonellik olgusu tarafından dizayn edilir. Amaç-rasyonelliğin zenginleşmeyi sağlamasına rağmen iktisadi hayatta adaletsizlikler üretmesi yoğun tartışmalara yol açar. Rasyonelleşme süreci sonrasında veya zenginleşmenin doğru yönetilememesi nedeniyle zengin-fakir arasındaki makasın her geçen gün daha fazla açılması sosyo-ekonomik hayatta birtakım krizleri ortaya çıkarır. Habermas'a göre modern toplumdaki adaletsizliklerin temelinde meşruiyet krizi, ekonomik kriz ve motivasyon krizi bulunur. Buna karşın o, insanı amaç edinen bir rasyonellik projesi tasarlar ve moderniteyi evrensel olarak kabul edilebilir bir düzleme oturtmaya çalışır. Bu çalışmanın amacı Habermas'ın moderniteyi haklı çıkarma girişimi olarak nitelendirilebilecek iletişimsel-eylem tasarımını 'zenginleşmenin doğru yönetimi' meselesi üzerinden ortaya koymak, bu itibarla evrensel ve rasyonel iyi-modern toplumun kurulabilmesi için gerekli doneleri eleştirel bir şekilde sunmaktır. Habermas, zenginleşmenin yönetiminde iletişim, özgürlük ve müzakereci demokrasiyi öne çıkarır. İletişimsel-eylem modeli ile birey ve toplumlar arasında barışı ve dayanışmayı üreten bir iletişsim ahlakını önerir. Habermas'ın görüşleri dar anlamda zenginleşmenin, geniş anlamda modernleşmenin tüm dünya toplumları üzerindeki olumsuz etkilerini gidermek amacı taşıdığından oldukça önem arz eder.

Anahtar Kelimeler: Modernite, İktisadi Adalet, Habermas, İletişimsel-Rasyonellik

\section{The Right Management of Enrichment in J. Habermas' Rationality Project}

\begin{abstract}
Individual and institutional activities are designed by interest-oriented purpose-rationality in modern life. Although purpose-rationality provides enrichment, the fact that it produces injustices in economic life causes intense discussions. After the rationalization process or due to the fact that enrichment is not managed correctly some crises occur in the socio-economic life. According to Habermas, there are legitimate crisis, economic crisis and motivation crisis. In contrast, he tries to place modernity on an acceptable level in the context of rationality, which aims human. In this context, the study aims to present Habermas' communication-action design, which can be described as an attempt to justify modernity, through the right management of enrichment and to present the necessary factors in order to establish a universal and rational good-modern society. He proposes a communication morality that generates peace and solidarity between individuals and communities and communicative-action that emphasizes communication, freedom and negotiator democracy in the management of enrichment. This effort is of great importance to relieve the negative effects of modernization on all world societies.
\end{abstract}

Key Words: Modernity, Economic Justice, Habermas, Communication-Rationalism

\section{Atıf İçin / Please Cite As:}

Çamlı, A. Y. (2021). J. Habermas'ın rasyonalite projesinde zenginleşmenin doğru yönetimi. Manas Sosyal Araștırmalar Dergisi, 10(1), 707-719.

Geliş Tarihi / Received Date: 09.06.2020

Kabul Tarihi / Accepted Date: 06.08.2020

\footnotetext{
${ }^{1}$ Dr. Öğr. Üyesi, Manisa Celal Bayar Üniversitesi, ahmetyavuz.camli@cbu.edu.tr

(iD) ORCID: 0000-0002-0746-9755
} 


\section{Giriş}

Batı'da modern kapitalizmin ortaya çıkışı ile ekonomiye dair tüm parametrelerde niteliksel ve niceliksel artışlar yaşanır. Araştırmalardan elde edilen verilere göre daha önce dünyanın hiçbir yerinde görülmeyen üretim miktarı ve artışı yalnızca kapitalizmi içselleştiren Batı toplumlarında kaydedilir. Ekonomik büyüme ve gelişme başarısına nail olan Batı toplumları zenginliği yönetme gibi çetrefilli bir sınava maruz kalırlar. Bu süreçte kapitalist toplumlar zenginleşme uğruna pek çok bedel öderler. Habermas'a göre zenginleşmenin sosyal maliyetleri arasında en ağırı aklın içeriği ve fonksiyonelliğindeki değişimdir. Akıl, çeşitli kategorilere bölünür ve biçimsel aklın (amaç-rasyonellik) dini aklı (pratikrasyonellik) perdelemesine tanık olunur. Diğer bir ifadeyle Batı, ekonomik zenginlik uğruna dini, ahlaki ve geleneksel olandan uzaklaşıp sekülerleşir. Değer alanları anlam üreten sosyo-kültürel sistemden kopar ve her biri kendi mantıksal çizgilerinde toplumu şekillendirir. Bu doğrultuda kapitalizm tüm toplumsal alanları kolonize eden bir sosyo-ekonomik organizasyon olarak tanımlanabilir.

Sonraki süreçte kapitalizmin kurumsallaştırdığı amaçsal-rasyonelliğe bağlı olarak krizler ortaya çıkar ve iktisadi hayattaki adaletsizliklerde sürekli artış görülür. Neredeyse bir yüzyıldır Batı düşünce dünyasında bireysel ve toplumsal bazda iyileştirme teorileri ortaya attlır. Bu itibarla Habermas en önemli ve kapsamlı teoriyi -iletişimsel-rasyonellik teorisini- sunan düşünürler arasındadır. Habermas’a göre amaç-rasyonelliğin egemenliği altındaki düzende, iletişimsel-rasyonellik baskılanmış ve silikleşmiş bir pozisyondadır. Düşünür bu noktada gerek rasyonellik gerekse eylem ve toplum nazarında kavramlaştırmalara ve çeşitlendirmelere başvurur. $\mathrm{O}$, eylem türlerini temel olarak ikiye ayırır. Bunlar amaç-rasyonel eylem ve iletişim-rasyonel eylemdir. Amaç-rasyonellik toplumsal formasyonlardan "sistem" alanını temsil eder. Sistem, Habermas'ın teorisinde maddi ve seküler alanı işaret eder. Birey eylemde bulunurken sistemden motivasyon sağlarsa amaç-araç-seçim sürecinde bu alanın sunduğu ilkelere göre hareket eder. Din, ahlak, gelenek gibi ögeler sistem alanı dışında tutulur. Bu çerçevede hâkim olan 'nesnel akıl'dır. Bireyi harekete geçiren esas dinamikler çıkar, para, haz, güç, makam, şöhret ve başarıdır.

İletişim-rasyonel eylem ise "hayat evreni"ne tekabül eder. Hayat evreni, dini ve ahlaki unsurların egemen olduğu alandır. Birey eylemde bulunurken hayat evreninden motivasyon sağlarsa amaç-araç-seçim sürecinde bu alanın sunduğu prensiplere göre faaliyette bulunur. Hayat evreninde çıkar, para, güç, makam, şöhret, başarı gibi unsurlar 'sistem'de olduğu gibi öncelikli değildir. Burada esas olan dini ve ahlaki değer ve ilkelerdir. Bundan dolayı iletişimsel-eylem, "kutsalın dilselliği" olarak ifade edilebilir.

Buraya kadar olan girizgâhta can alıcı noktalarına değinilen Habermas'ın iletişimsel-eylem teorisine ve bu teoriye bağlı olarak modern toplumda zenginleşmenin doğru yönetimi imkânının olup olmadığ1 tartışmasına geçmeden önce bir temel oluşturması açısından modernizmin, rasyonelleşmenin veya amaçsalrasyonelliğin sonuçlarına değinilecektir.

\section{Zenginleşmenin Ortaya Çıkardığı Problemler}

Kapitalist sistem doğal olarak sınıflı bir toplum üzerine inşa olunmuştur. Hatta bu özellik kapitalist sistemin temel şartlarından biridir. Kapitalist toplum pür haliyle burjuva ve proletarya sınıfları olmak üzere iki sınıftan oluşur. Üretim araçlarının mülkiyeti burjuva sınıfının elindedir. Proletarya sınıfinın emeği dışında satacağı bir değeri yoktur. Devlet kurumları burjuva sınıfının egemenliği ve ağır baskısı altındadır. Yani devlet bürokrasisi ekonomik sistemden gelen direktifleri yerine getiren bir organizasyondan ibarettir. Doğal olarak her iki sınıfın çıkarları birbirine zıttır. Birindeki artış ya da genişleme öbüründe azalma ya da daralma demektir. Yani bir tarafta kitlelerin çıkarları, diğer tarafta belli bir azınlığın çıarları söz konusudur. Siyasal sistemin dizaynında toplumsal çıkarlar dikkate alınmaz; sadece burjuva sınıfının çıkarları güvence altına alınır. Bu yapısal problem, sistemin zorunlu olarak toplumun nıza ve hoşnutluğundan uzaklaşması demektir. Bu sistemde yasalar ve yönetmelikler toplumsal konsensüsle değil, azınlığın arzuları doğrultusunda yapilır. Bu durum ise politik sistemin ve buna bağlı olarak ekonomik sistemin toplumsal meşruiyetten mahrum kalmasına yol açar. Toplumsal meşruiyetin olmaması toplumun devlete olan sadakat ve güvenini zedeler. Sürecin bu şekilde işlemesi sonucunda sosyal bütünleşme sağlanamazken toplumsal parçalanma ve polarizasyon da kaçınılmaz olur. Bu da kapitalist veya modern toplumun özünde meşruiyet krizi barındırmasına yol açar.

Toplumun zenginleşmesi sürecinde dini ilke ve değerlerin, geleneğin ve ahlakın dışlanması meşruiyet krizini doğurur. Habermas bu kriz türünü Durkheim ile Weber’in düşüncelerinden geliştirir. Geleneksel dönemde gerek ekonomik sistemin gerekse politik sistemin meşruiyet kaynağı din, ahlak ve gelenek gibi kaynaklardır. Modern hayatta ise bu kaynakların anlam üretme fonksiyonu etkinliğini yitirir. Durkheim 
bilinçli bir şekilde dışlanan din, ahlak, gelenek gibi kaynakların yerine modern hayatta herhangi bir kaynağın keşfedilemediğini belirtir. $\mathrm{Bu}$ nedenle $\mathrm{o}$, politik ve ekonomik sistemin ahlaki ilkelerin düzenlemesinden mahrum kaldığını iddia eder. Ona göre sonuç, toplumsal çözülme ve bunalımlardır. Doğal olarak toplumdaki bireyler meşruiyet kaybından etkilenirler. Bu nedenle toplumsal hayatta suç ve intihar oranları yükselir. Durkheim bireylerin iç dünyalarında meydana gelen şiddetli depremlerin yol açtı̆̆ bu krizleri "anomi teorisi" altında ele alır (Durkheim, 1979, ss. 241-242).

$\mathrm{Bu}$ patolojik problemler Weberyen sosyolojide çok daha güçlü şekilde vurgulanır: Weber'e göre kapitalizm ortaya çıkış aşamasında meşruiyetini Protestan Etik'ten temin eder. Toplumda disiplinli bir çalışma ile yaratııının rızasının kazanılacağı görüşü hâkimdir. Metodik (disiplinli ve rasyonel) çalışma hayatı bireyin ebedi kurtuluşunun bir belirtisi olarak algilanır. Özellikle Protestanlığın Kalvinizm kolu kitleleri harekete geçiren itici güçtür. Kalvinist dogma, dini hassasiyetin etkili olduğu bir dönemde insanlara (cehennem azabından) kurtulmuşluğun formülünü verir. Kalvinizm asketik (çilekeş), metodik, sistemli ve disiplinli mesleki çalışmanın etkili olabileceğini öne sürerek inananları ilkeli çalı̧maya motive eder. Bununla yetinmeyip bireylerin hazcılık, gösteriş, israf, savurganlık, bencillik gibi olumsuzluklardan uzak durmalarını ögütler. Protestanlık, yaratılan ve yaratıcı arasında Katoliklerin benimsediği aracı ve engelleri kaldırarak insanı yaratıcısıyla baş başa bırakır. Bu şekilde insan sosyal hayatında giderek yalnızlaşır ve bireyselleşir. Batı insanı iç dünyasında yapayalnız hisseder ve bu durumun verdiği (olumsuz) motivasyon ile iktisadi hayatta amaç-rasyonel hareket eder. Bütün eylem ve kararlarını kendi çıkarına göre düzenler. Para, haz, güç, makam ve başarı uğruna yaşayan -kapitalist- insana dönüşür. Bu süreçte dini, ahlaki ve geleneksel unsurlar saf dışı edilir. Ekonomi, hukuk ve siyaset gibi değer alanları, birbirleri arasındaki organik bağlardan arınarak kendi mantıklarına göre yeniden inşa edilirler ve seküler niteliğe sahip olurlar. Bu sürecin sonucunda insan, özne konumunu kaybeder; güç ve para için bir meta gibi araçsallaştırılır (Weber, 1950, s. 69-71; 1965, ss. 252-261).

Weber'e göre zenginleşmenin doğru yönetilememesi sonucunda birey “anlam kaybı"na maruz kalır. $\mathrm{O}$, dini ve ahlaki değerlerin insanlara anlam sunma fonksiyonunu yitirmesini anlam kaybı olarak ifade eder. Rasyonelleşmeye bağlı olarak "hayat evreni"nin tüm canlı renkleri silikleşir ve monoton bir yapı ortaya çıkar. Başka bir söylemle "dünyanın büyüsü bozulur". İnanç, kutsallık, sadakat, doğruluk, dürüstlük ve güven gibi değerler popülaritesini ve etkisini kaybeder. Bu unsurlar gibi insanı etkileyen ve yönlendiren başka bir değerler seti oluşturulamaz (Weber, 1950, s. 259). Yani hukuk, sanat ve bilim gibi alanlar yeni formatlarıly (rasyonel ve seküler) dünyası tatsızlaşan ve renksizleşen Batı insanına herhangi bir değer üretemezler.

Anlam kaybı ya da kültür trajedisinin ekonomi alanına sızması kaçınılmazdır. Modern iktisadi sistemde araçlar -araçsal rasyonellik-, rasyonel amaçları domine eder. İşçi, her gün kullandığı ve sahibi olduğu iş araçlarından soyutlanır ve onun esiri olur. Adeta dönen çarkın bir dişlisi ya da bir 'şey' haline gelir. Weber'e göre rasyonelleşmenin ikinci yıkıcı sonucu bu noktada tezahür eder; "özgürlük kaybı" (Weber, 1950, s. 209). Kapitalist sistem insanın dünyasını bir fabrikaya dönüştürür. Metalaşan insanı ve mekanikleşen ilişkileri barındıran bu sistem; çıarsız ilişki, iletişim, güven, sadakat, dürüstlük gibi tüm değer içerikli dinamikleri ortadan kaldırır, insanı insan yapan duyguların içeriğini boşaltır. Para, makam, güç, hırs, haz, cinsellik ve başarıyı putlaştırarak insanlı̆̆ın nihai amacı konumuna yükseltir. Weber’in söylemiyle eskiden insanlar bir puta taparken şimdilerde binlerce puta taparlar. Düşünür, modern dönemi "yeniputperestlik" çağı olarak ifade eder. Gerekli bütün duyguları, amaçları, değerleri çalınan birey özgürlüğünü kaybeder ve bu soğuk dünyada "demir kafes"te bir 'şey' olarak yaşamaya mahkum edilir (Weber, 1950, s. 123). Yani kapitalist Batı toplumları demir kafesi andırırlar. Bu mekanik yığınlar "düşüncesiz uzmanlar, hissiz hedonistler" olan yöneticiler ve çarkın dişlisi haline dönüşen insanlardan (yönetilenlerden) meydana gelir (Weber, 1950, s. 145).

Weber'in bu görüşlerini Habermas kısaca şöyle açıklar: Modern öncesi dönemde anlam ve aidiyet üreten alt sistem sosyo-kültürel sistemdir. Bu sistem dini, sanat1, teolojiyi, felsefeyi, ahlakı ve adaleti bünyesinde barındırır. Anlamın yeniden üretilmesi sanatla, teolojiyle, felsefeyle olur. Sosyo-kültürel sistemden ilk kopan ekonomik sistem ve politik sistemdir ve bu değer alanları artık kendi içsel mantıklarıyla hareket eder. Ekonomik ve politik sistemin temel unsurları para ve güç olur. Ahlakın ve değerlerin etkinliğini kaybetmesi para ve gücün toplumsal alanlar üzerinde egemenlik kurmasına yol açar. Rasyonelleşmenin, modernleşmenin, zenginleşmenin sonucu olarak hem aidiyet, meşruiyet ve motivasyon krizleri hem de ekonomik kriz baş gösterir. Meşruiyet krizine ilişkin olarak toplumsal organizasyonda 
bölünmeler, parçalanmalar ve ayrışmalar yaşanır. Bireysel hayatta şeyleşme, yabancılaşma ve psikolojik problemler ortaya ç1kar (Habermas, 1984, s. 143).

Öte yandan motivasyon krizi, meşruiyet ve aidiyet krizine bağlı olarak ortaya çıkan diğer kriz türüdür. Motivasyon krizi daha çok iş hayatında çalışanlar üzerinde teşekkül eder. Emek sahibi kişilerin üretim aşamasında harcadıkları enerji karşıllğında aldıklarından tatmin olmamaları nedeniyle oluşur. Çalışanlar hak ettiklerini alamadıklarında zamanla çalışma istek ve heveslerini kaybederler. Bilindiği üzere artı-değerin üretici birimlere adil bir şekilde dağıtılması emeğini sunanların haklarını alması demektir. Peki modern kapitalist toplumlarda üretim araçları sahiplerinin bu konuya yaklaşımları nasıldır? Sermayedarlar sermaye birikimini daha da arttırmak için sunulan emeğin mübadele değerini attırıp kullanım değerini azaltırlar. Ayrıca meydana çıkan artı-değeri doğrudan kendilerine almak isterler. Zira birimlere pay edilecek her değer, sermayedarların artı-değerinden eksilir. Bu husus çalışan insanların heveslerini, şevklerini, isteklerini kırar ve giderek motivasyonlarını ortadan kaldırır (McCormick, 2015, s. 194-195).

Motivasyon krizi doğal olarak ekonomik krizi üretir. Kapitalizmin domine ettiği toplum kısır bir kriz döngüsünün içindedir. Habermas’a göre sivil toplum ve kitle demokrasisi gibi söylemler arttıkça toplumsal talepler problemleri hafifletmek amacıyla kısmen karşılanmaya çalışıllır. Böylece kitlesel tüketim ve toplumsal refah artmaya başlar. Bunun anlamı bir yandan olumlu gelişmeler yaşanırken diğer yandan artıdeğerin giderek azalması gerçekleşir. Bu durumun devam etmesi sermaye birikimini yavaşlatır yahut durma noktasına getirir. Artı-değerin tasarrufa ayrılamaması, yatırımların yavaşlamasına ve ekonomik büyüme hızının düşmesine ya da kötü bir sonuç olarak büyümenin eksi düzeyde (küçülme) gerçekleşmesine yol açabilir. Yani kapitalist toplum derin bir çelişkiye maruz kalır. Ekonomik krizi önlemek ya da krizden kurtulmak için bir tercih yapmak zorunda kalır. Bir tarafta rasyonellik diğer tarafta sosyal ve insani politikalar toplumun tercihine sunulur (Habermas, 1973, ss. 15-18).

Habermas'ın düşüncesinde kapitalizm, Weber'in karamsar olarak gördüğü dönemi aşıp llımlı kapitalizm aşamasına evrilir. Bu aşamada, kapitalist firmalar arasındaki rekabet eski yıkıcı ve eziciliğini kaybeder. Devlet, özel sektörün ulaşamadığı ve yetersiz kaldığı alanlarda devreye girer, firmaların kâr haddinin düşmemesi için çeşitli alanlarda yatırımlar yapar. Demokrasinin ve sosyal güvenliğin gelişmesi meşruiyet krizinin etkilerini azaltabilir. Habermas'a göre bu aşamada üç önemli gelişme yaşanır. İkinci Dünya Savaşı'ndan sonra yaşanan gelişmeler kapitalizmin krizlerini hafifletmede önemli adımlar olarak görülür. Öncelikle bu dönemde devlet müdahaleleri çok önemli hale gelir. Bilindiği üzere klasik anlayışa göre piyasada devletin müdahalesi arzu edilmezken 1929 ekonomik buhranından sonra Keynesyen politikalar devletin piyasada etkin rol almasını sağlar. Bu sayede devlet sistemin özüne uygun şekilde işleyişi kontrol eder ve krizleri kısmi olarak engeller. Diğer önemli gelişme kitle demokrasisinin derinleşmesi ve yaygınlaşmasıdır. Politik sistem meşruiyet gereksiniminin farkına varır ve bunu toplumdan karşılamak ister, bireyleri de katılımcı siyasete ortak eder. Sermayedar kesim, demokratik yollardan ihtiyac1 olan kanunlar1 çıkartmaya çalışır. Demokrasinin etkisini arttırması bireysel özgürlüğü arttırdığı gibi çok partili hayat ve seçimler de işçi partilerinin iktidar olabilmelerine imkân tanır. Üçüncü önemli gelişme ise devletin sosyal nitelik kazanmasıdır. Böylelikle sosyal ve iktisadi adalete yönelik adımlar atılır (Habermas, 1987, ss. 349351).

Habermas'ı özellikle İkinci Dünya Savaşı'ndan sonra ortaya çıktığını iddia ettiği gelişmeler kapitalist sistemin daha insani niteliğe doğru evrilmesini sağlar. Ona göre sistem henüz tam anlamıla insani bir karaktere sahip olmasa da gelişmeler sayesinde toplumsal tabakalar arasında tırmanan gerilim yumuşar, kısmi anlaşmalara varılır, meşruiyet krizi hafifler ve çalışan kesim proleterya konumundan vatandaşlığa yükselir. Buna rağmen Habermas'a göre kapitalist sistemde hedonist ve egoist anlayış baskınlığını hissettirirken insanın araçsallaştırılmasının önüne tam olarak geçilmiş değildir (Timur, 2017, s. 210). Buna karşın o iletişimsel-rasyonellik teorisiyle seküler ve dini kesimlerin diyalog kurmaları gerektiğini belirtir. Özellikle dini değerlerin içeriğini oluşturan adalet, ahlak ve iletişim gibi prensiplerin kamu alanında etkin olmaları gerektiğini belirtir.

\section{İletişimsel-Rasyonellik Teorisi}

Habermas genel olarak ideal modern toplumu, özel olarak iktisadi ve sosyal hayattaki adaletsizlikleri giderme ya da zenginleşmeyi doğru yönetme üzerine kurulu bir paradigma inşa etme peşindedir. Bu nedenle modern hayatın tahrip ettiği sosyo-kültürel alanı yeniden yapılandırma çabasındadır. Bu amaca yönelik olarak düşünsel birikiminin rekoltesini oluşturan "iletişimsel-rasyonellik teorisi"ni ileri sürer. İletişimsel-rasyonellik projesinin mihenk taşı "iletişim" olgusudur. Bu teoride, özellikle seküler ve dini kesimlerin iletişimle dizayn edilen ilişkileri revizyona tabi tutulur (Habermas, 1990, s. 364; Taylor, 1991, s. 
23; Cooke, 1998, s. 5). Habermas'a göre bireylerin birbirleriyle anlaşması kurulan ilişkinin ve iletişimin ası1 amacıdır. İletişim eyleminin gerçekleşmesi esnasında bireyler "hayat evreni" denilen değerler havuzundan motivasyon sağlar. Bu şekilde gerçekleşen iletişimsel-rasyonel eylem geçerlilik ilkesine sahiptir. Bir eylemin geçerli olabilmesi için taraflar görüşlerini belirli kıstaslar eşliğinde öne sürmelidirler. Bu faaliyetteki metodiklik bireyi rasyonel düşünme ve davranışa yönlendirir. Sürecin tamamlanmasıyla çıkar yönelimli amaçsal-rasyonellikten farklı olarak iletişimsel-rasyonellik olgusuna ulaş1ır (Flyvbjerg, 1998, s. 219). Düşünüre göre bu anlayışla hareket eden tüm toplum kesimleri uzlaşmaya varacak, üretilen ortak payda sayesinde evrensel ahlaki normların ve hukukun ortaya çıkması kolaylaşacak, aynı zamanda iktisadi hayatta adil bir sistem inşa edilebilecektir. Dolayısıyla Habermas iletişimsel-rasyonellik olgusuyla; tüm değer alanlarını kolonize eden amaçsal-rasyonel eyleme karşılık iletişimsel-rasyonel eylemi önerir (Dallmayr, 1988, s. 565).

Amaçsal-rasyonel eylem; deneysel bilgiye dayalı, teknik süreçlerin oluşturduğu, özünde araç-amaçseçme rasyonelliklerini barındıran eylem tipidir (Habermas, 1970, s. 92; Weber, 1947, s. 170). Habermas amaç-rasyonel eylemi yöntem olarak ikiye ayırır. Bunlar araçsal eylem ve stratejik eylemdir. Bu eylem türlerinde bireyin kendi çıkarı ön plandadır. Çıkara ve başarıya yönelik eylem bireyler arasındaki ilişkileri mekanikleştiren (ruhsuzlaştıran) niteliktedir. Araçsal eylemde birey belirlediği amaca çeşitli araçlarla yönelir. Eylemin tamamen çıar odaklı olması ve amaca koşulsuz dönüklügü, araçların belli bir çerçevede seçilmesini önemsizleştirir. Silah üreticisi olan ülkelerin terör örgütlerine silah satması araçsal eyleme örnek verilebilir. Stratejik eylemde ise birey yine çıkar odaklı ve amaca koşulsuz dönüktür. Ancak araçsal eylemden farklı olarak burada uygun araç ya da yöntemler tercih edilir. Kapitalist firma davranışları stratejik eyleme örnektir (Habermas, 1984, ss. 284-288; Jones and Allmendinger, 1998, s. 1980).

Bununla birlikte Habermas amaç-rasyonel eylemden üç alt eylem tipi geliştirir. Alt eylem tipleri teleolojik eylem, değersel eylem ve dramaturjik eylemdir. Teleolojik eylemde birey bir amaç belirler. Bireyin amacı ve sistem arasında bilgiye dayalı bir bağ vardır. Amacı gerçekleştirecek araçlar araçsal-rasyonelliğe karşılık gelir. Bir nüans farkı olarak çıkarı garanti etmede karşıdaki bireyin kararları etkiliyse stratejik eylem söz konusu olur. İkinci alt eylem tipi değersel eylemdir. Mevcut ya da geçerli normatif kurallara göre hareket eden birey normlara göre düzenlenmiş eylemde bulunur. Dolayısıyla bu eylem tipi meşru bir tabana sahiptir (Thompson, 1983, s. 285). Üçüncü alt eylem tipi dramaturjik eylemdir. Bu tarz eylemde bireyin amacını bizzat gerçekleştirmekten ziyade karşısındakine amacına dönük niyetini veya düşüncesini aktarmas1, bilgi vermesi ve onu etkilemesi söz konusudur (Habermas, 1984, s. 85-86). Tüm bunlardan ayr1 olarak Habermas'ın asıl odaklandığı eylem tipi ise iletişimsel-rasyonel eylemdir.

\section{İletişimsel-Rasyonel Eylem}

Habermas, referans aldığı Weber’i aynı zamanda eleştirerek ve sonunda ondan bayrağı devralarak eylem kategorilendirmesinde yeni bir cephe açar ve teorisini sağlam bir zemine oturtmaya çalışır. Yani o, bireyin toplum içinde güvenli, barışçl ve saygın bir şekilde yaşamasına imkan tanıyan iletişimsel eylemi gün yüzüne çıkarma gayretindedir. İletişimsel eylemin genelleşmesi ise zenginliğin doğru yönetimini sağlayacaktır.

Ona göre iletişimsel eylem genel olarak bireylerin karşılıklı düşüncelerini, taleplerini, ihtiyaçlarını öne çıkarıp bir anlaşmaya varmaları durumudur (Habermas, 1995, s. 58). Bu eylem türünde en az iki aktörün herhangi bir konuda fikir birliğine ulaşıp anlaşmalarını dil ve eylem yetisiyle sağlamaları gerekir. İletişimsel eylemin gerçekleşmesi bireylerin bütünleşmesi anlamına gelir. Toplumdaki tüm kesimlerin iletişimsel eylemde bulunması toplumun ya da toplumların ortak paydada buluşmasını ifade eder. Bu açıdan Habermas iletişimsel eylem ile rasyonel toplumda evrensel anlaşma dinamiklerini tespit, tesis ve terfi etmeye çalışır (Habermas, 1970, s. 92; Dallmayr, 1988, s. 558). Bireyler iletişimde bulunurken konuya ilişkin görüşlerini bildirirler. Karşılıklı olarak zıt görüşler ya da farklı görüşler ortaya atılabilir. Bu süreç anlaşma neticeli bir eğilimi gösterir. 'Anlaşma', eyleme ya da tartışmaya iştirak edenlerin öne sürdüğü görüşlerin bazı şartlar altında ve ilkelere göre düzenlenmesi sonucunda ulaşılan bir durumdur. $\mathrm{Bu}$ bakımdan her iletişimsel eylem Habermas’a göre rasyonel değildir (Habermas, 1984, s. 86).

Rasyonel toplumu oluşturacak iletişimsel-rasyonel eylem bir takım ön şartlara ve ilkelere dayanır: Habermas'a göre aktörler (birey, firma, kurum, devlet) öncelikle anlaşma amaciyla birbirleriyle iletişim kurmalıdır. Anlaşma amacıyla iletiş̧im kuran taraflar birbirini tanımalıdır. Karşı tarafın bir özne olarak bu süreçte yer aldığı en başta kabul edilmelidir. Bir uzlaşmanın sağlanabileceği (sonuç kesin olmasa da) inanc1 içine girilmelidir. Yapıcı olma niyetiyle bir araya gelinmelidir. Her aktörün beklentisini karşılayan ortak 
normlar belirlenmelidir. Bu normlar tüm kesimler tarafindan bilinen, anlaşılan ve kabul edilen nitelikte olmalıdır. Tartışmaya eşit konumda başlanılmalıdır. Dil, özgür ve etkili bir şekilde kullanılmalıdır. Niyetler açık ve net bir şekilde sunulmalıdır. Anlaşılır ifadeler kullanılmalı, dürüst olunmalı ve güvenilir bir duruş sergilenmelidir. Eylemin tamamlanma sürecinde şiddet, yalan, aldatma, hile, tahakküm gibi uygun olmayan davranışlara başvurulmamalıdır. Karşı görüşlerin doğru ve geçerli olarak savunulduğu idrak edilmeli ve yeni tartışmalara hoşgörüyle yaklaşılmalıdır (Habermas, 1995, ss. 87-89).

Bütün bu şartların yanı sıra Habermas'ın düşüncelerine dayanarak iletişimsel-rasyonel eylemin ilkeleri de ortaya çıarılabilir. Karşılıklılık ilkesi iletişimsel eylemde bulunan öznelerin eşit şartlar altında, fikirlerini sunmaya imkan ve haklarının olduğunu ifade eder (McCarthy, 1982, s. 58). Değerler ilkesi rasyonel iletişimsel eylemde şartların eşit olması ve uygunsuz davranışların kabul edilmemesi arzulanır. $\mathrm{Bu}$ doğrultuda belirli değerlerin eylem sürecinde ilke olarak ele alınması gerekir. Saygı, dayanışma, samimiyet, dürüstlük gibi değerler genel anlamda bir ilkeler demetini oluşturur (Fraser, 1985, s. 106). Geçerlilik ilkesine göre birey düşüncesini uygun kanıt, belge ve argümanlarla savunmalıdır. Bu yüzden iletişimrasyonel eylemde geçerli olduğu öne sürülen farklı görüşlerin rekabeti söz konusudur. Savunduğu görüşün doğru olduğunu söyleyen özne, müzakere esnasında bunu geçerli kılmak için önceden bahsedilen şartlara uygun davranmalıdır. Buna göre bireyin görüşü anlaşılır, doğru ve geçerli olmalı, karşı tarafin anlayacağ1 şekilde söylemde bulunmalı ve nihayetinde her zaman gerçekleşmese de anlaşmaya ulaşma inancinda olmalıdır. Elbette birey doğru söylemlerde bulunmalı, ortak normlara göre hareket etmeli ve samimi ifadelerde bulunmalıdır (Habermas, 1984, s. 101). İdeal konuşma ilkesi, herhangi bir kişi veya grup tarafindan baskıya maruz kalmadan ya da kısıtlanmadan bireyin özgürce fikirlerini açıklamasıyla gerçekleşir (Habermas, 1973, s. 110). İdeal konuşma ilkesine dayalı gerçekleşen anlaşmaya göre ortaya konulan görüşler doğru ve geçerli kabul edilir. Taraflar eşit firsatlara sahip olarak birbirini anlama çabasına girişirler. Genel olarak tüm kesimlerin iletişimsel-rasyonel eylem şartlarını sağladığ1 ve ilkeli hareket ettiği bilinir (Habermas, 1995, s. 198). Habermas'a göre doğruluk ilkesinin içerdiği doğru görüş, yapılan müzakere sonucunda karşı tarafın kabul ettiği görüştür. Bu açıdan doğruluk ilkesi toplumda genel bir uyumun tesisi açısından önemlidir. Habermas doğruluk ilkesini dört aşamalı söylem tipinin birleşiminden elde eder. Bunlar sırasıyla şöyledir: Fikirlerin daha iyi anlaşılması için kullanılan sözcüklerin oluşturduğu "iletişimsel söylem", önerilerin anlamını ifade eden "sabitleştirici söylem", görüş belirten bireyin savunmasının anlamını belirten "temsil edici söylem" ve son olarak "kural içerikli söylem". Bu ayrıştırmanın amacı doğru veya yanlış görüşü ortaya çıkarma zemini oluşturmaktır. Doğru olduğuna inanılan düşünce söz edimleri ile savunulur. Müzakerede doğru olarak öne sürülen görüş tartışmaya açık olarak savunabilir, kabul görmeyebilir ya da onaylanabilir. Neticede kabul edilen 'doğru' görüş geçerlilik arz eder. Doğruluk ilkesiyle birlikte normatif meşruluk ve samimilikten bahsedilebilir. Bu açıdan iletişimsel-rasyonel eylemde bireyin söylemi anlaşılır, gerçek, doğrulanmış ve samimi nitelikte olmalıdır (Habermas, 1995, s. 58). İletişimselrasyonel eylemin doğruluk ve geçerlilik ilkeleri tabii olarak argümantasyona ihtiyaç duyar. Doğruluk onaylanma gerektirdiğinden ve doğru olan görüşün geçerli kabul edilmesinden hareketle iddianın olgusal unsurlarla desteklenmesi icap eder. Argümanların iddianın doğruluğunu garantileme özelliği bulunur. Bir eylemin anlaşmayla sonuçlanabilmesi için söyleme rasyonel argümanlarla katılmak önemlidir. Hatta zorunluluk arz ettiği de iddia edilebilir. Çünkü argümanlar bireylerin görüşlerini geçerli kılabileceği gibi muhatabı ikna olmaya da yönlendirebilir. Ayrıca argümantasyon süreci ideal konuşma ilkesinin de bir parçası kabul edilir. Bu bakımdan anlaşmaya varılan bir eylemde geçerli olan argüman diğerinden daha kanıtlayıcı ve güçlü olan argümandır (Müller, 2004, s. 398).

Bahsedilen şartlar ve ilkelerden de anlaşılacağı üzere Habermas'in meydana çıkardığı iletişimsel rasyonellik, iletişimsel eyleme bağlı ilişkilerin oluşturduğu bir durumu ifade eder. İletişimsel eylem teorisi toplumda genel olarak anlaşmayı tesis eden bir formulasyondur. Bu paralelde Habermas bir başka açıdan teorisini izah etmeye çalışır. Düşünür iletişimsel-rasyonelliğe bir çerçeve sunan 'hayat evreni' ve amaçsalrasyonelliği temsil eden 'sistem' ayrımına yönelir.

\section{Hayat Evreni ve Sistem}

Habermas toplumsal formasyon olarak iki temel alandan söz eder. Bunlar farklı özelliklere sahip ve içerdiği rasyonellik türü ve işlevleri birbirinden çok ayrı olan hayat evreni ve sistem alanlarıdır. Habermas'a göre sistem; yönetim ve ekonomi gibi maddi ve dış dünyayı ifade ederken hayat evreni ise dini değer ve ilkelerin bulunduğu alanı tanımlar. Sistem, birey-nesne arasındaki ilişkiden, hayat evreni ise birey-birey arasındaki ilişkiden beslenir. Sistemde para, çıkar, güç, başarı hegemonik unsurlar iken hayat evreninde iletişimsel-rasyonel eylemin içerdiği ilke ve değerler özümsenir. 
Hayat evreni ve sistem ayrışması rasyonelleşmenin, sekülerleşmenin, modern kapitalizmin ya da modernleşmenin kaçınılmaz bir sonucudur. Bilindiği üzere Protestan Etik tarafindan rasyonelleşmeye tabi tutulan hayat evreni ilerleyen süreçte burjuvai zihniyete yenik düşüp etkisiz hale getirilir. Her ne kadar günümüz kapitalist toplumlarında, hayat evreni sistemin baskısı ve gücü karşısında direncini yitirmiş, adeta sistemleşmiş bir görünümde olsa bile Habermas hayat evrenini komuta eden sistemin kaotik haline çözümü yine hayat evreninde arar (Habermas, 1991, s. 226; 1987, s. 154, 374; 1984, s. 74).

Habermas'ın kuramında ana zemini oluşturan hayat evreni, bireyin iletişimsel-rasyonel eylemde bulunması esnasında gerek kendi davranış ve görüşlerine anlam üreten gerekse karşı tarafin davranış ve görüşlerini algılama şeklini oluşturan bir kültür ve özgürlük alanıdır (Habermas, 1987 s. 148; Duran, 2017, s. 232). Hayat evrenine bağlı yaşamını sürdüren birey, rasyonel toplumu oluşturan uzlaşmanın bir nedeni, parçası ve amacıdır. Böyle bir toplumda birey dayanışma ve paylaşma içinde eylemde bulunur (Habermas, 1984, s. 70). Hayat evreni bireyin toplumdaki mevcut kültür ve bilginin taşı1ıcısı ve kullanıcısı olmasını sağlar. Aynı zamanda MacIntyre'ın 'pratik' kavramında (MacIntyre, 2007, ss. 187-188) olduğu gibi birey o zamana kadar üretilen bilgi birikimine sahip olup onu geliştirme firsatını da elinde tutar. Dolayısıyla toplumsal ve ahlaki normları içselleştiren birey rasyonel toplumun kurucu ve geliştirici öznesi haline gelir.

Habermas dil ve kültür alanı olarak gördüğü hayat evreninin yapısal dinamiklerini kültür, toplum ve kişilik olarak tespit eder. Habermas'a göre kültür, iletişimsel eylemde bulunan tarafların anlaşmaya varılmaya çalışılan herhangi bir konu hakkında ileri sürdükleri iddia, görüş ve argüman için ihtiyaç duyulan sözsel ve fikirsel birliği garanti eden bilgi haznesidir. Hayat evreninin diğer yapisal dinamiği olan toplum, düşünürün nazarında iletişimsel eylemde bulunanların aidiyet hissettikleri kesimlerden oluşan ve dayanışmanın kol gezdiği meşru organizasyondur. Kişilik ise bireye konuşma ve eyleme yetisi veren kazanımlarını ve kimliğini ifade eder (Habermas, 1984, s. 142).

Bu doğrultuda rasyonel toplum dizaynı için amiral gemisi rolünü üstlenen hayat evreni insana çeşitli statüler (birey, vatandaşlık) sunar. Hayat evreninin kurumsal niteliği olarak görülebilecek bu durumda özel alan ve kamusal alan ayrımı oluşur. Özel alan bireyin ailesi, çevresi, üye olduğu dernekleri temsil eder. Kamusal alan ise medya ve kamuoyundan teşekkül eder. Sistem ve hayat evreni arasındaki sosyal organizasyona göre sistemin alt kademelerinden birini oluşturan ekonomi ile insanın birey olarak konumlandığ1 özel alan, sistemin diğer kademesini oluşturan yönetim ile insanın vatandaş olarak konumlandığı kamusal alan arasında bir işbirliği mevcuttur. Özel alanın temsilcisi birey (hayat evreni), ekonomi (sistem) alanına hem işgücü sağlar hem de bu alanda talep oluşturur, karşllı̆ında ise ihtiyaçlarını karşılamak için bu alandan mal, hizmet ve ücret temin eder. Kamusal alanın temsilcisi vatandaş (hayat evreni), yönetim (sistem) alanında yasalara riayet ederek devlete vergi verir, karşıllı̆ında bu alandan çeşitli hizmetler elde eder (Habermas, 1984, s. 340; McCarthy, 1984, s. xxiv). Dolayisiyla bu iki yap1 arasinda çatışma ve ayrışmadan ziyade dayanışma ve paylaşma söz konusu olmalıdır. Belirtilmelidir ki hayat evreninin sistemi oluşturan alt-sistemlerin birbirleriyle bağlantısını sağlama ve bu şekilde toplumsal ahengi tesis etme fonksiyonu da vardir.

Habermas dini ilke ve değerlerin her iki toplumsal yapıyı bütünleştirici rolünü vurgulayarak iletişimselrasyonelliği öne çıkarır. Habermas'ın asıl gayesi amaç-rasyonelliğin modernleşme sürecinde tahrip ettiği ve pasifleştirdiği hayat evrenini yeniden dizayn etmektir. Bu çaba toplumsal eylemi beraberinde getirir. Toplumsal eylemlerin birleştirici nitelik içermeleri ve rasyonel toplum inşası için meşruluk üretebilmeleri kamusal alanda geçerli kabul edilmelerine bağlıdır. İletişimsel-rasyonelliğin kamusal alana yansıması; ortaya atılan fikirlerin müzakere edildiği, görüşlerin doğruluk süzgecinden geçirildiği ve iletişimsel-rasyonel eylemin sağladığı anlaşmaya ulaşılan bir duruma karşılık gelir. Kamusal alan, hayat evreninin bir parçası olarak sivil toplum kuruluşları vasıtasıyla kurumsallaşan bir iletişim evrenidir denilebilir. Kurumsallaşan kamusal alan bilginin refere edildiği, farklı bilgi çeşitlerinin üretildiği ve bunların müzakerelerle şekillendirildiği bir ortamdır. Bu bağlamda kamusal alan bireylerin özgürce ve eşit biçimde ilişki kurduğu ve iletişimde bulunduğu bir alan olarak devreye girer. Bu alanda gerçekleşen tartışmalarla bireyler esas amaçlarının bilincine varıp hayatlarına yön veren normları belirlerler (Habermas, 1984, s. 337, 340; 1987, s. 77).

\section{İletişim Ahlakı}

Daha önce zikredildiği üzere Habermas evrensel bir iletişim ahlakını modern topluma entegre etmeye çalışır. Onun kurguladığı iletişim ahlakı, post-seküler bir toplumda huzuru, güveni, barışı, özgürlüğü tesis 
eden; kaosu, kargaşayı, çözümsüzlüğü ortadan kaldıran; dolayısıyla bireylerin fikir birliği içinde hareket edebileceği ortamı sağlayan ahlaki ilkelerin olgunlaşma süreci olarak izah edilebilir.

Habermas iletişimsel eylem teorisiyle bireyleri, firmaları, devletleri ve tüm toplumsal değer alanlarını kapsayan bir iletişim ahlakı organize etme gayretindedir. Ona göre iletişimsel-rasyonel eylem ilke ve şartlarının bir bütün olarak kavranması ve sürece dahil edilmesiyle iletişim ahlakına ulaşılabilir (Delanty, 1997, s. 38). İletişimsel eylem taraflarının öne sürdükleri argümanların, iddiaların, önerilerin geçerliliği, kurallara uygunluğu ve meşruluğu etik açıdan önemlidir. İletişimsel-rasyonelliğe göre bireyin iddialarının kabul edilebilir olması için üç çeşit sorgulama düzeyinden geçmesi gerekir. Birinci aşamada bireyin nesnel dünyada bir şeye gönderme yapıp yapmadığı, ikinci aşamada ortak yaşam dünyasına gönderme yapıp yapmadığı ve son aşamada kendi öznel dünyasına gönderme yapıp yapmadığı gözlemlenir (Sunstein, 2008, s. 92). Buna göre sorgulamadaki ilk aşamada, iletişimin gerçekleşmesinde ve iddiaların sunulmasında herkes tarafından doğrudan benimsenen normlar geçerlidir. İletişimsel eylemin gerçekleşmesi esnasında doğrudan benimsenen ahlak normlarının sorgulanması gündeme gelir. Bireyin yapısından kaynaklanan ahlaki davranışını motive eden normlar eleştiriye tabi tutulur, bunların geçerlilikleri ve bağlayıcılıkları tartışılır. Sonraki aşamada konuya ilişkin olarak çevreyi ya da toplumu kapsayan iyi, akılcı ve bağlayıcı olabilecek kanıtlar öne sürülür. Bu noktada bireylerin talepleri normu oluşturan bir dinamik niteliğindedir. Normun inşa edilmesi ya da kavranması evrenselleşmeye geçiş olarak görülür. Yani bireylerin doğal ihtiyaçlarının neler olduğunun sorgulanması gerekir ve herkes için bu türden ihtiyaçların karşılanması söz konusu ise eylemi karşılayan norm ya da normlar ortaya çıkar. Böylelikle normlar ihtiyaçlara dönük olarak meşru yollarla tespit edilirler. Taraflar taleplerini kolay, doğru ve gerçeğe uygun bir şekilde aktaracak dil kullanmalıdırlar. Argüman oluşturmadaki üçüncü adımda bireyler bilgi ve beceri düzeyine göre bahsedilen ihtiyaçlar çerçevesinde nelerin talep edilebileceğini formüle ederler. Bu aşamalar aynı zamanda ideal konuşma ilkesini tanımlar.

Bu yöntem toplumdaki anlaşmazlıklar ve çatışmalar durumunda ilgili herkesi bağlayan bir çözüm için izlenecek yolu gösterir. Yani Habermas evrensel etik anlayışıla herkes tarafindan onaylanan bir yöntem ortaya koymak ister (Habermas, 1995, s. 66). Bu minvalde Habermas'ın iletişim etiğine imkan tanıan evrenselleştirilebilirlik meselesinden kısaca bahsedilmelidir.

İletişimsel-rasyonel eylem ilke ve şartlarının herkes tarafindan geçerli görülmesi buradaki asıl konudur. Böylece evrenselleştirilebilirlik iletişimsel eylemle ulaşılmak istenen anlaşmanın bir sınanması olarak görülebilir (Habermas, 1995, ss. 94-97). Evrenselleştirilebilirlik ilke olarak bireylere eylemlerin sonuçlarından etkilenebilecek tüm bireylerle diyaloğa geçmeyi ve sınama yapmalarını ister (Habermas, 1995, s. 197). Habermas'ın düşüncesinde evrenselleştirilebilirlik toplumsal konsensüs açısından garanti kaynağıdır. Bireyler kendi faydaları zarar görmedikçe bir ahlaki ilke ve içeriği kabul edebilirler. Onların bu ahlaki ilkeye gösterdiği rıza bir ahlaki geçerlilik veya hakkaniyet ölçüsü olarak görülmemelidir. Burada dikkat edilecek husus rasyonel anlaşmanın sağlanmasıdır. Gösterilen rıza, nihai bir amaç olarak algılanmamalıdır; ahlaki geçerlilik yolunda atılması gereken rasyonel bir adım olarak kabul edilmelidir. Daha önce izah edilen iletişimsel-rasyonel eylemin kuralları nazara alınarak yapılan müzakere veya tartışmanın sonuçlanması şöyle ifade edilebilir: Ortaya konulan norm ve değerlerin tartışılması, sınanması ve neticede bir anlaşmaya varılması durumunda baştaki tartsşılan norm evrenselleştirilebilirlik eleğinden başarıyla geçmiştir. Elde edilen norm bireylerin hem kamusal alandaki hem özel alandaki veya iktisadi hayattaki eylemlerinde şüphe duymaksızın dikkate alınabilir. Habermas'a göre elde edilen norm mutlak yanlıslanmaz değildir; rasyonel tartışmalarda tekrar ele alınabilir. Önemli olan normların evrenselleştirilmesinden ziyade geçerlilik yöntemidir (Habermas, 1995, s. 48).

\section{İletişim Teorisi Eleştirisi}

Habermas çok kapsamlı bir teori inşa etmeye çalıştı̆̆ından tabii olarak birçokları tarafından farklı cephelerden eleştiriye tabi tutulur. Onu eleştirenler arasında en dikkat çekenler elbette Hiristiyan teologlardır. Çünkü Habermas, iletişimsel-rasyonelliği kısmen amaç-rasyonelliğe karşı ikame eder. Amaçrasyonelliğin dini ve ahlaki ilkeleri dışlamasının sonuçları ise ortadadır. Bu nedenle onun teorisine ciddi ve yapıcı eleştiri getirenler daha çok Hıristiyan teologlarlardır. Bu düşünürler Habermas'in iletişim teorisinin eksiklerine değinip buna bağlı yeni teolojiler üretirler. Teologların teslis, enkarnasyon veya son akşam yemeği gibi dini inançları vurgulamaları bir yana, onların genel olarak İbrahimi geleneği savunan çizgide olmaları konumuz açısından önem arz eder.

$\mathrm{Bu}$ doğrultuda politik teoloji yaklaşımını benimseyen teologlar Habermas'ın iletişim fikrini destekleyen anlayıştadırlar. Siebert'e göre insanın insan gibi yaşamasını sağlayan unsur iletişimdir. Kişi ne 
kadar iletişimde olursa o derece insandır. Sosyal hayata katılma, sorumluluk alma ve pratiğe dönük olma iletişimin içerikleridir. Bunun yanında iletişim insanın var olmasıyla da ilişkili bir olgudur. İnsan varlık sahnesine iletişim sayesinde çıkar ve ademden kurtulur (Siebert, 1985, s. 373). Oysa Habermas'in iletişim olgusu bireyler arasında sığ bir alanda değerlendirilir. İnsanın yaratan ve madde ile olan iletişimi göz ardı edilir. Teologlara göre bu durum iletişimin gerçeklikten uzak konumlanmasına neden olur.

Dinbilimcilerin Habermas'a yönelik en önemli eleştirisi evrensel dayanışma konusundadır. Onlar Habermas'n post-seküler teorisini bir zorlama olarak görürler. Peukert'e göre iletişimsel-rasyonelliğin tutarlılığ1 dinle kurduğu ilişkiye bağlıdır. Çünkü Peukert, iletişim ahlakı teorisinde göze çarpan evrensel dayanışma olgusunun tarihsel kapsamda ele alınmasının zorunluluğunu savunur (Peukert, 1984, ss. 25-26).

Peukert'in elbette Habermas'ı onayladığı hususlar vardır. Ona göre arzu edilen ideal düzeyde bir konuşma, sınırsız iletişim toplumunu işaret eder. İletişim ahlakı bu tarz bir iletişim toplumundan üretilir. Sınırsız özgürlük ayırt etmeksizin herkes için olmalıdır ve bu durum bireyleri birbirine bağlar. Bunun için ihtiyaç duyulan ise evrensel dayanışmadır. Ancak Habermas'ın sınırsız iletişim toplumu bireyi tatmin etmemektedir: Bu toplumun tasarım planı nedir? Evrensel dayanışmanın strateji haritası nasıldır? $\mathrm{Bu}$ anlatılanlar somut gerçekliğe nasıl dökülecektir?

Öte yandan Peukert'e göre sınırsız iletişim ve evrensel dayanışma insanı insan yapan özelliklerdir. Habermas'n bu duyarsızlığı teolojik eleştiriyi zorunlu kılar. Peukert bu konuda Lenhardt'a başvurarak Habermas'ı moderniteyi haklı bulma ve olumlama konularında eleştirir. Lenhardt'a göre geçmiş nesillerin mutsuzluğu göz ardı edilip gerçek bir mutluluk tasarımının ortaya çıarılması mümkün değildir. Bu girişim tarih şuurunun silinmesini öngören amnesia problemine işaret eder (Newlands, 1997: 276).

Ayrıca birey geçmiş nesillerin acılarını unutup kendi mutluluğuna odaklanırsa evrensel dayanışma nasıl sağlanabilir? Burada egoist bir kişiden bahsedilir. Bu sebeple Peukert'e göre evrensel dayanışma; Yahudilik, Hiristiyanlık ve İslam gibi büyük peygamberli dünya dinlerinin ilke ve değerlerinin pratiğe dökülmesiyle gerçekleşebilir. Anlaşılacağı üzere Habermas'ın seküler iletişim teorisi Hıristiyan teologlar tarafından yapıcı bir şekilde eleştirilir ve ona teolojik bir derinlik kazandırılır (Simpson, 1989, ss. 532-537).

\section{Habermas'ın Müzakereci Hukuk Tasarımı}

İletişimsel-rasyonellik merkezli zenginleşmenin doğru yönetimi ya da iktisadi adaletin sağlanabilmesi için Habermas'ın müzakereci hukuk tasarımı da ele alınmalıdır. Habermas'ın hukuk sistemi siyaset ve ahlakla ilişkilidir. Ona göre politik sistem yasama, yürütme ve yarg1 erklerine sahiptir. Sistemin çevresi iç periferi ve dış periferiden oluşur. İç periferiyi sosyal güvenlik kurumları veya işçi sendikaları gibi kurumlar, dış periferiyi sivil kesimler tanımlar. Hukuk sistemi, politik sistemin özünde yer alır. Ayrıca Habermas'ta hukuk ve ahlak birbirinin tamamlayıcisı olarak ifade edilir.

Zenginleşmeyi doğru yönetecek ya da iktisadi ve sosyal adaleti sağlayacak hukuk, toplumsal müzakerenin gücüne ve inancına bağıdır. Müzakerenin fili çevresini informel kamu alanı, prosedür gereği yasama faaliyetinin yapıldığı parlamento formel kamu alanı oluşturur. Müzakerenin yapıldı̆̆ı informel kamu alanı; çıartılması düşünülen kanunla ilgili içeriğin toplumdaki tüm kesimlerin tartışmasına aç1k olduğu üniversiteler, medya, sendikalar, tiyatrolar gibi oluşumlardır. Bu kurumlarda rasyonel argümanlarla tartışma sonucunda tezahür eden iletişim gücü, formel kamu alanında yönetim gücüne evrilir. Habermas bu süreci güç sirkülasyonu olarak tanımlar. Yani Habermas, politik sisteme bağlı popüler egemenlik ve birey özgürlüğünü karşılayan bireysel otonomi arasında bir diyalog kurmaya çalışır. Ona göre bu süreçte müzakereci hukuk daha önce gelenek ve dinin üstlendiği sosyal entegrasyonu sağlama veya anlam üretme yükümlülüğünü üstlenir (Habermas, 1996, ss. 28-31).

Habermas teorisinde sosyal meşruiyet ve ideal meşruiyeti birlikte içselleştirmeye çalışır. Özellikle müzakereci hukukun ideal meşruiyeti sağlayacağına inanır. Ona göre hayat evreninin rasyonelleşmesi düşüncesi sosyal meşruiyete karşıllk gelir. Meşruiyet biçimlerini açıklamada facticity ve validity kavramlarına başvurulur. Facticity bir yasanın pozitif nitelikte, tahmin edilebilir veya kesin, kurumsal bağlantı içinde ve yaptırım gücüne sahip olmasıdır. Validity ise bir yasanın toplumsal kabule konu olmasıdır. Bu itibarla Habermas meşruiyeti temel haklarla birlikte değerlendirir. Temel hakları yasal güvenceyle garanti altına alan anayasal demokrasiyi meşru olarak görür. Burada temel hukuk ile validity, anayasal demokrasi ve kurulma prosedürü ile facticity bağlantılıdır (Duran, 2017, ss. 133-135).

Yani Habermas'in temel hak kategorileri bireysel ve kamu otonomisi, insan haklar1 ve popüler egemenlik arasındaki anlaşmazlıkları bir düzleme oturtma girişimi olarak bilinir. Bu çaba müzakere ilkesini 
işaret eder. Bu ilke yasa ve ahlak arasında tarafsızdır. Müzakerenin esas fonksiyonu norm ve kurumların din ve metafizik tarafından meşrulaştırılmasının mümkün olmadığı bir düzende meşrulaştırıcı olmasıdır. Habermas'a göre meşru normlar, sonuçlarından etkilenecek tüm bireylerin rasyonel müzakerede bulunarak ortak paydada anlaştıkları normlardır. Bu durum bazı temel hak kategorilerine ihtiyaç duyar. O, iletişimselrasyonel eylemin ilkelerini bu sürece entegre eder (Habermas, 1996, s. 49). Habermas'ın buradan çıkardığ1 sonuç; gerek kamu otonomisi gerekse özel otonomi ya da temel haklar ve popüler egemenlik olsun hiç biri diğerinden üstün değildir. Hepsi aynı anda olan durumlardır ve aralarında bir ilişkiyi barındırırlar.

Anlaşılacağı üzere Habermas'a göre hukuk ve ahlak birbirlerinin tamamlayıcısıdır. Ahlak evrensel ve soyut iken hukuk toplumsal ve somuttur. Ahlakın maddi yaptırım gücü yoktur oysa hukuk yaptırım gücüne sahiptir. Ahlak mekan ve zamandan bağımsızdır. Adalet geleneksel dönemdeki insan için de modern insan için de önemlidir. Adalet duygusu, ahlakın bünyesinde konumlanır. Hukuk, ahlakla aynı olmasa bile onun ahlak tarafindan meşrulaştırılması gerekir. Ayrıca hukuk somut olaylarda adalete nasıl ulaşılacağını tespit etmeye çalışmalıdır. Zira adalet ilkesinin insanlar tarafından ortaya çıkarılması düşük bir ihtimaldir. Hukuk tarafindan açık ve net kurallar konularak adaletin maddeleştirilmesi ve pratik eyleme dökülmesi mümkündür. Öte yandan hukuk, kişinin egoist davranıp karşı tarafin hakkını ihlal etmesini önleyebilir. Çünkü modern hayat ahlakı ve dini dışlayan seküler niteliktedir. İş bölümünün ve uzmanlaşmanın yaygınlaştığ şehir toplumlarında egemen olan stratejik ve çıarcı eylem türüdür. Bu nedenle Habermas’a göre modern hayatta egoist ve hedonist kişilerin davranışlarını yönetmenin tek aracı budur.

\section{Tartışma, Sonuç ve Öneriler}

Modern kapitalizm, meşruiyet kaynağını para, güç, haz, başarı, hırs gibi unsurlara dayandıran ve Batı toplumlarında ortaya çıkıp neredeyse tüm toplumları etkisi altına alan ekonomik ve politik bir sistemdir. Kapitalist organizasyonun yapısı gereği hukuk, sanat, bilim, kültür gibi alanların hepsi bu sistem tarafindan domine edilir. Değer alanlarının kapitalizm anlayışına angaje olması aynı zamanda rasyonelleşme süreci olarak bilinir. Rasyonelleşme, toplumsal organizasyonları organik bağlarından koparıp dini, ahlaki ve insani niteliklerinden bağımsız bir dönüşüm içine girmelerine yol açar. Bu nedenle 19. yüzyıl ortalarından günümüze kadar pek çok bireysel ve toplumsal problem baş gösterir.

İnsanı tam anlamıyla bir 'araç, meta, şey' haline dönüştüren bu manevi hezeyanı yok etmek amacıyla birçok düşünür ve filozof farklı teoriler geliştirir. Zenginleşmenin doğru yönetimi doğrultusunda Alman filozof Habermas da tüm toplumsal şubeleri kapsayan "iletişimsel-rasyonellik" adını verdiği rasyonel bir toplum dinamiği geliştirir. Habermas'ın çözümlemesinde insan, adeta terkedildiği insanlık-dışı alandan layık olduğu 'özne’ konumuna yükseltilmelidir. Habermas'a göre modern zamanda insana gerçek hüviyetini kazandıracak doğru kanal rasyonel iletişimdir. İnsanlar gibi iletişim kuran bütün aktörler (firma, devlet, dernek ve diğerleri) eylemde bulunurken, karar alırken ya da problem çözerken güç, para, başarı tarafindan güdülenmeden karşılıklı konuşma, paylaşma ve dayanışmayı önemseyerek hareket etmelidirler. Bu esnada karşılıklı rızanın tesis edilmesi gerekir.

Dolayısıyla iletişim ahlakı sistemden ya da sistemi oluşturan siyaset ve ekonomi gibi alt-sistemlerden ayrı düşünülemez. Müzakere etiği ile dizayn edilen siyaset, ekonomi ve hukuk gibi toplumsal alt sistemlerin aynı zamanda bireylerin kendi aralarında ve diğer birimlerle olan ilişkilerinin ve birimlerin karşlıklı diyaloglarının meşruluğu, doğruluğu, geçerliliği, kabul edilebilirliği evrensel iletişim ahlakının tamamlanması olarak ifade edilebilir. Yani Habermas bu yöntemi iletişim kuran tüm birimler arasında geçerli olabilecek şekilde tasarlar. Düşünür, iletişimsel-rasyonellik ile sistem ve hayat evreni alanlarını diyaloga davet eder. Böylelikle düşünür modern toplumun değersel onarımını rasyonel bir çerçevede yapmaya çalışır.

Habermas ortaya koyduğu hukuk teorisinin aşkın nitelikte olmadığını aksine belli bir toplumsal gerçekliğe ait olduğunu savunur. Onun müzakereci hukuk tasarımı hayat evreni ve sistem arasında bir köprü olarak işlev görür. İletişim teorisinin genel amacı kamu alanında müzakereler sayesinde inşa edilen iletişim gücünün yönetimde yönetim gücüne aktarılması ve iletişim gücüyle yönetim gücünün kontrol edilmesidir. Bu noktada düşünür "politik gücün sirkülasyonu" kavramından bahseder. Para ve gücün hayat evrenini işgal etmesi nedeniyle iletişim yolları kapatılır ve toplumda stratejik eylemlerin hüküm sürdügü görülür. Bu tarz toplumda hukuk devreye girerek yönetici araçlar olan güç ve para arasında bağlayıcı ve yapıcı bir rol üstlenir. Modern toplumda hukuk sistemiyle para ve gücün fonksiyonları garanti altına alınır. Hukuk, hayat evreni kaynaklı müzakere süreci tarafindan meşrulaştırıllıken yönetici araçlara kurumsal bir güven temin eder. Bu nedenle hukuk, iletişimi ve sosyal entegrasyonu sağlama fonksiyonuyla donanır. Yani Habermas'ın düşündügü demokratik yasama faaliyeti, iletişim ve yönetim güçlerini bağdaştırır ve hukuk, hayat evreni ile sistem arasında koordinasyon sağlama görevine talip olur. 
Bu bakımdan günümüzde iletişimsel-rasyonelliğin mikrodan makroya bütün ekonomik kurum, ilişki ve faaliyetlerde esas alınmasına şiddetle ihtiyaç olduğu söylenebilir. Zenginleşmenin yönetiminde iletişim yani özgürlük ve müzakereci demokrasiyi öne çıkaran iletişimsel-eylem ile birey ve toplumlar arasinda paylaşmayı ve dayanışmayı teşvik eden bir iletişim ahlakı savunulabilir. Bunun yanında kendisine ve ürettiğine yabancılaşan ve kendini bir 'şey' gibi gören bir kişinin patolojik rahatsızlıklarından kurtulması için dini, ahlaki ve insani değerlerle donanmış bir iletişim modelini benimsemesi gerektiği de ileri sürülebilir.

\section{Etik Beyan}

"J. Habermas'ın Rasyonalite Projesinde Zenginleşmenin Doğru Yönetimi” başlıklı çalışmanın yazım sürecinde bilimsel, etik ve alıntı kurallarına uyulmuş; toplanan veriler üzerinde herhangi bir tahrifat yapılmamış ve bu çalışma herhangi başka bir akademik yayın ortamına değerlendirme için gönderilmemiştir. Bu araştırmada doküman incelemesi yapıldığından etik kurul kararı zorunluluğu bulunmamaktadır.

\section{Kaynakça}

Durkheim, E. (1979). Suicide: A study in sociology (J. A. Spaulding \& G. Simpson, Trans.). New York: The Free Press.

Cooke, M. (1998). Introduction. M. Cooke (Ed.). Jürgen Habermas, on the pragmatics of communication (pp. 1-19). Cambridge, Massachusetts: MIT Press.

Dallmayr, F. (1988). Habermas and rationality. Political Theory, 16(4), 553-579.

Delanty, G. (1997). Habermas and occidental rationalism: The politics of identity, social learning, and the cultural limits of moral universalism. Sociological Theory, 15(1), 30-59.

Duran, B. (2017). Din ve kapitalizm. Lambert Academic Publishing.

Flyvbjerg, B. (1998). Habermas and Foucault: Thinkers for civil society?. The British Journal of Sociology, 49(2), 210-223.

Fraser, N. (1985). What's critical about critical theory? The case of Habermas and gender. New German Critique, 35, 97-131.

Habermas, J. (1970). Technology and science as ideology. J. Habermas (Ed.), Toward a Rational Society: Student Protest, Science, and Politics (pp. 81-122). Boston: Beacon Press.

Habermas, J. (1973). Legitimation crisis. London: Heinemann.

Habermas, J. (1984). The theory of communicative action I. Boston: Beacon Press.

Habermas, J. (1987). The theory of communicative action II. Boston: Beacon Press.

Habermas, J. (1990). The philosophical discourse of modernity: Twelve lecturers. Massachusetts: The MIT Press.

Habermas, J. (1991). A reply in Axel Honneth and Hans Joas, communicative action: Essays on Jürgen Habermas' the theory of communicative action. Cambridge, Massachusetts: MIT Press.

Habermas, J. (1995). Moral consciousness and communicative action. Cambridge: MIT Press.

Habermas, J. (1996). Between facts and norms: Contributions to a discourse theory of law and democracy (W. Rehg, Trans.). (2. Press). Massachuetts, Cambridge: The MIT Press.

Jones, M. T. \& Allmendinger, P. (1998). Deconstructing communicative rationality: a critique of Habermasian collaborative planning. Environment and Planning a Economy and Space, 30(11), 1975-1989.

MacIntyre, A. (2007). After virtue: A study in moral theory (3rd. ed.). Indiana: University of Notre Dame Press.

McCarthy, T. (1982). Rationality and relativism: Habermas's 'overcoming' of hermeneutics. J. B. Thompson and D. Held (Ed.), Habermas: Critical Debates (pp. 57-78). London: The Macmillan Press.

Mccarthy, T. (1984). Translator's introduction: Jürgen Habermas, reason and the rationalization of society. Volume 1 of the Theory of Communicative Action. Boston: Beacon Press.

McCormick, J. P. (2015). Weber, Habermas ve Avrupa devletinin dönüssümü (Çev. F. B. Aydar). İstanbul: Türkiye İş Bankası Kültür Yayınları.

Müller, H. (2004). Arguing, bargaining and all that: communicative action, rationalist theory and the logic of appropriateness. European Journal of International Relations, 10(3), 395-435.

Newlands, G. M. (1997). Generosity and the Christian future. Eugene: Wipf and Stock Publishers.

Peukert, H. (1984). Science, action, and fundamental theology: Toward a theology of communicative action. Cambridge, Massachusetts: MIT Press.

Siebert, R. J. (1985). The critical theory of religion. The Frankfurt School, Mouton, New York-Amsterdam.

Simpson, G. M. (1989). Theologia Crucis and the forensically fraught world: Engaging Helmut Peukert and Jürgen Habermas. Journal of the American Academy of Religion, 57(3), 509-541.

Sunstein, C. R. (2008). Neither Hayek nor Habermas. Public Choice, 134(1-2), 87-95.

Taylor, C. (1991). Language and society. In Honneth A. and Joas H. (Ed.), Communicative Action (pp. 23-35). Cambridge: Polity Press.

Thompson, J. B. (1983). Rationality and social rationalization: an assessment of Habermas's theory of communicative action. Sociology, 17(2), 278-294.

Timur, T. (2017), Habermas' okumak (3. Basım). İstanbul: Yordam Kitap. 
Weber, M. (1947). The theory of social and economic organization (A. M. Henderson and T. Parsons, Trans.). London: William Hodge and Company Press.

Weber, M. (1950). The Protestant ethic and the spirit of capitalism (T. Parsons, Trans.). (3rd ed.). Charles Scripner's Son, New York.

Weber, M. (1965). The sociology of religion (E. Fischoff, Trans.). Boston: Beacon Press.

\section{EXTENDED ABSTRACT}

Emerging in Western societies and influencing almost all societies in Habermas' thought, modern capitalism is an economic and political system that bases its legitimacy source on elements such as money, power, pleasure, success and ambition. Due to the structure of the capitalist organization, all areas such as law, art, science, culture are dominated by this system. The engagement of value fields in the understanding of capitalism is also known as the process of rationalization. Rationalization causes social organizations to break their organic ties and enter a transformation independent of their religious, moral and human qualities. For this reason, many individual and social problems arise from the mid-19th century to the present day.

Many thinkers and philosophers develop different theories for the destruction of this spiritual delusion, which the thinkers call in various expressions, which literally turns people into a 'tool, commodity, thing'. In line with the proper management of enrichment, the German philosopher Habermas also develops a rational social dynamics called 'communicative-rationality' which concerns all social branches. In the analysis of Habermas, the human should be raised to the 'subject' position he deserves from the inhumane area he was abandoned. According to Habermas, the right channel that will make people real in modern time is rational communication. All actors communicating like people (firm, state, association and others) should act while taking action, making decisions, or solving problems, taking care of mutual speech, sharing and solidarity without being motivated by power, money, success. Meanwhile, mutual consent must be established.

Therefore, the morality of communication cannot be considered separately from the system or from sub-systems such as the politics and economy that make up the system. The legitimacy, correctness, validity, acceptability of social sub-systems such as politics, economy and law designed with negotiation ethics, as well as the mutual dialogue of individuals, with other units and the mutual dialogues of the units can be expressed as the completion of universal communication morality. In other words, Habermas designs this method to be valid among all communicating units. The thinker invites the areas of communicative-rationality and system and life universe to dialogue. In this way, the thinker tries to make a worthwhile repair of modern society with a rational solution.

Habermas argues that the law theory he has put forward is not transcendent, but that it belongs to a certain social reality. Its negotiator legal design functions as a bridge between the universe of life and the system. The general purpose of the communication theory is to transfer the communication power built in the public field through the negotiations to the management power in management and to control the communication power and the management power. At this point, the thinker talks about the concept of the circulation of political power. Since money and power occupy the universe of life, the means of communication are closed and it is seen that strategic actions prevail in society. In this type of society, the law comes into play and plays a binding and constructive role between power and money, which are executive tools. In modern society, the functions of money and power are guaranteed by the legal system. While the law is legitimized by the negotiation process originating from the universe of life, it provides institutional trust to the executive tools. Therefore, the law is equipped with the function of providing communication and social integration. In other words, the democratic legislative activity that Habermas thinks connects the communication and management forces and aspires to provide coordination between the law, the universe of life and the system.

As it is understood, according to Habermas, the law and morality are complementary to each other. While morality is universal and abstract, law is social and concrete. Morality does not have a material sanction power, whereas it has a law enforcement power. Morality is free from space and time. Justice is important for both modern and modern people. The sense of justice is positioned within morality. Even if the law is not the same as morality, it must be legitimized by morality. Besides, the law should try to determine how justice can be achieved in concrete events. Because the principle of justice is unlikely to be revealed by humans. By establishing clear rules by the law, it is possible to materialize justice and put it into practical action. On the other hand, law can prevent the person from acting egoistic and violating the 
right of the other party. Because modern life is secular in which morality and religion are excluded. It is a type of strategic and self-interested action that dominates urban communities where the division of labor and specialization is common. According to Habermas, this is the only tool to manage the behavior of egoist and hedonist people in modern life.

In this respect, it can be said that communication-rationality is needed to be based on micro to macro in all economic institutions, relations and activities. In the management of enrichment, communication, the action that emphasizes communication, freedom and negotiator democracy, and morality of communication that promotes sharing and solidarity among individuals and societies can be advocated. Besides it can be argued that a person who is alienated to himself and what he produces and who sees himself as a thing should adopt a communication model equipped with religious, moral and human values to get rid of his pathological problems. 